\title{
EFFECT OF NITROGEN IN BACKING GAS ON DUPLEX ROOT WELD PROPERTIES OF HEAVY- WALLED PIPE
}

\author{
A.M. Sales ${ }^{1 *}$, E.M. Westin ${ }^{2}$, P. Colegrove ${ }^{3}$ \\ ${ }^{1}$ ConocoPhillips, Perth, Western Australia \\ ${ }^{2}$ voestalpine Böhler Welding, Böhler Welding Str. 1, 8605 Kapfenberg, Austria \\ ${ }^{3}$ Cranfield University, Welding Engineering Research Centre, Cranfield, Cambridgeshire, UK. \\ *Present address: K-TIG Pty Ltd - Research \& Development Centre, Adelaide, South Australia
}

\begin{abstract}
Duplex stainless steels are increasingly used for offshore subsea components as the technology allows for deeper recovery of oil \& gas reserves. Alloy UNS S31803 (EN 1.4462 / UNS S32205) combines high strength with good resistance to pitting and crevice corrosion. This grade is alloyed with nitrogen and has good weldability. For heavy-walled process piping intended for subsea sour service, the properties of the root pass are of high importance. For this reason, the effect of using nitrogen in the backing gas was investigated. Test pieces were manually welded with the gas tungsten arc welding (GTAW) process using ER2209 filler wire. Tensile, bending and hardness testing was carried out and showed acceptable results across all specimens. Higher contents of nitrogen in the backing gas showed more austenite formation and a significant increase in pitting corrosion resistance when compared with pure argon. With $\mathrm{Ar}+2 \% \mathrm{~N}_{2}$, there was no pitting, but a small weight loss of 1.7 $\mathrm{g} / \mathrm{m}^{2}$ was measured. $10 \% \mathrm{~N}_{2}$ was required to pass both the corrosion tests ASTM G48 Method A $\left(4 \mathrm{~g} / \mathrm{m}^{2}\right)$ and ASTM A923 $\left(1 \mathrm{~g} / \mathrm{m}^{2}\right)$. The highest average impact toughness was achieved with pure nitrogen as the backing gas.
\end{abstract}

\section{INTRODUCTION}

Ferritic-austenitic (duplex) stainless steels have a dual phase microstructure consisting of approximately equal amounts of ferrite and austenite, which provide excellent mechanical and corrosion resistance properties. Welding ultimately alters the phase balance affecting the properties of the weldment. Duplex weld solidification is primarily ferritic and transformation to austenite is through a solid-phase transformation. Initial austenite formation takes place intergranularly followed by Widmanstätten side plates. Early production of ferriticaustenitic stainless steels often resulted in an unequal balance of the two-phase microstructure of approximately $70 \%$ ferrite and 30\% austenite, which posed problems with ductility and in-service corrosion resistance $[1,2]$. The introduction of nitrogen into the duplex base material, filler metals and shielding gases greatly improved the weldability and localized corrosion resistance of duplex alloys [3]. Additions of nitrogen were reported as enhancing austenite formation, ductility and increased resistance to corrosion [4,5]. This improved weldability has contributed to increased demand for duplex materials across all industries. When using over-alloyed filler metals, the resulting duplex weld metal will have ferrite levels of between $30 \%$ and $70 \%$, depending on primarily alloy composition, cooling rates and heat input [3].

The gas tungsten arc welding (GTAW) process is the most common process used for root beads on duplex pipe and the addition of a backing gas is used to prevent excessive oxidation of the root pass. When pure argon is used for the shielding and backing gas some nitrogen loss occurs, which increases the amount of ferrite in the microstructure and in turn can have a negative effect on the weld metal properties. Nitrogen can be added to the shielding and backing gases to avoid this occurring. The effects of using nitrogen in the shielding and/or backing gas has been investigated by various authors who have reported an increased resistance to pitting corrosion by increased austenite formation and lower levels of chromium nitrides in the weld metal microstructure [3,6-12].

It is known that multi-pass duplex welding can have unfavourable effects on the phase balance of preceding weld passes when compared with thinner duplex sections [4,13,14]. Root weld properties of those thicker sections have not been extensively investigated. Busschaert et al. [15] investigated impact toughness of a selection of forged flanges and $25 \mathrm{Cr}$ duplex pipe material welded by GTAW for subsea applications. Charpy V-Notch $(\mathrm{CVN})$ tests across a range of low temperatures showed consistent high impact energy values for the weld metal specimens down to $-100^{\circ} \mathrm{C}$. Westin et al. [7] investigated the effects on mechanical and microstructural properties of superduplex $(25 \mathrm{Cr})$ welded material using different gas mixtures on $16 \mathrm{~mm}$ thick $25 \mathrm{Cr}$ base material. The root and cold passes were welded with the GTAW process and flux-cored wire used for filling the joint. This study highlighted the use of three different backing gases and reported that only the backing mix of $90 \% \mathrm{~N}_{2}+10 \% \mathrm{H}_{2}$ passed the pitting corrosion test following ASTM G48 while the $100 \%$ Ar and $100 \% \mathrm{~N}_{2}$ gas failed. The highest CVN impact toughness value, however, was obtained when using pure Ar.

Heavy-walled pipe used for the collection of hydrocarbons subsea are increasingly exposed to harsh conditions and the internal root welds are exposed to high levels of $\mathrm{H}_{2}, \mathrm{H}_{2} \mathrm{~S}$, and $\mathrm{CO}_{2}$. The expectation for a lengthy service 
life therefore places a high degree of quality control on the designer and fabricator to obtain the optimum properties of the weld during the manufacturing process. This investigation thus focuses on the properties of root welds in as-welded condition in $23 \mathrm{~mm}$ thick $22 \mathrm{Cr}$ duplex piping. The objective of this work was to determine the effect of nitrogen on the root weld microstructure of multi-pass welded duplex and how this in turn affects the mechanical properties and pitting corrosion resistance.

\section{EXPERIMENTAL}

The base material was $\varnothing 250 \times 23.01 \mathrm{~mm}$ duplex seamless pipe of ASTM A790 UNS S31803 / EN 1.4462 (also fulfils UNS S32205) type in solution annealed condition. The filler metal was Ø $2.4 \mathrm{~mm}$ ER2209 solid wire. The chemical compositions are shown in Table 1.

Table 1: Chemical composition of base and filler metal (wt\%)

\begin{tabular}{llllllllll}
\hline & $\mathbf{C}$ & Si & Mn & P & S & Cr & Ni & Mo & N \\
\hline Base metal & 0.022 & 0.48 & 1.73 & 0.01 & 0.0007 & 22.34 & 5.04 & 3.14 & 0.17 \\
Filler metal & 0.020 & 0.47 & 1.60 & 0.016 & 0.0005 & 23.01 & 8.65 & 3.10 & 0.17 \\
\hline
\end{tabular}

Welding was performed manually using the GTAW process with direct current using electrode negative polarity. The welding position was $5 \mathrm{G}$ and a single V-groove joint preparation was used with a 4 mm root gap that included bridging tacks. The equipment used was a Lincoln Invertec V405-TP with an air-cooled welding gun that utilised a $2.4 \mathrm{~mm}$ thoriated tungsten electrode. As Table 2 shows, the backing gas ranged from pure argon to pure nitrogen. The shielding gas was $\mathrm{Ar}+2 \% \mathrm{~N}_{2}$ for all welds apart from when pure argon was used as backing gas. In addition to the root and cold passes, around 19-20 filling and capping runs were required to complete each weld. Welding commenced once the level of oxygen in the backing gas was below 100 ppm, which was monitored with an oxygen analyser. The backing gas was maintained until the cap layer was made. The interpass temperature for each pass was below $100^{\circ} \mathrm{C}$. The welding parameters are presented in Table 3 .

Table 2: Shielding and backing gas mixes

\begin{tabular}{lll}
\hline Number & Shielding gas & Backing gas \\
\hline 1 & $\mathrm{Ar}$ & $\mathrm{Ar}$ \\
2 & $\mathrm{Ar}+2 \% \mathrm{~N}_{2}$ & $\mathrm{Ar}+2 \% \mathrm{~N}_{2}$ \\
3 & $\mathrm{Ar}+2 \% \mathrm{~N}_{2}$ & $\mathrm{Ar}+10 \% \mathrm{~N}_{2}$ \\
4 & $\mathrm{Ar}+2 \% \mathrm{~N}_{2}$ & $\mathrm{Ar}+20 \% \mathrm{~N}_{2}$ \\
5 & $\mathrm{Ar}+2 \% \mathrm{~N}_{2}$ & $\mathrm{~N}_{2}$ \\
\hline
\end{tabular}

Table 3: Welding parameters

\begin{tabular}{lllllll}
\hline $\begin{array}{l}\text { Weld } \\
\text { pass }\end{array}$ & $\begin{array}{l}\text { Weld run } \\
\text { sequence }\end{array}$ & $\begin{array}{l}\text { Current } \\
{[\mathbf{A}]}\end{array}$ & $\begin{array}{l}\text { Voltage } \\
{[\mathbf{V}]}\end{array}$ & $\begin{array}{l}\text { Travel speed } \\
{[\mathbf{m m} / \mathbf{m i n}]}\end{array}$ & $\begin{array}{l}\text { Heat input } \\
{[\mathbf{k J} / \mathbf{m m}]}\end{array}$ & $\begin{array}{l}\text { Backing gas } \\
\text { flow rate }[\mathbf{l} / \mathbf{m i n}]\end{array}$ \\
\hline 1 & Root & $95-105$ & $9-10$ & $30-35$ & $1.4-1.8$ & 20 \\
2 & Cold pass & $120-130$ & $9-10$ & $80-90$ & $1.0-1.2$ & 20 \\
$3-18$ & Fill & $165-170$ & $11-12$ & $70-85$ & $1.3-1.7$ & 20 \\
$19-22$ & Cap & $150-155$ & $11-12$ & $65-80$ & $1.5-1.7$ & $3-5$ \\
\hline
\end{tabular}

All welds were subject to non-destructive radiographic testing. Cross-sections of the welds were prepared and polished to $1 \mu \mathrm{m}$ finish using standard metallographic techniques and examined in both un-etched and etched conditions. Electrolytic etching was performed in $40 \% \mathrm{NaOH}$ for detecting detrimental intermetallic phases and $40 \% \mathrm{KOH}$ for phase balance measurements. The ferrite content was measured in accordance with ASTM E562 [14] and the average given with 95\% confidence interval. The samples were taken from 9 o'clock position. Vickers microhardness testing with a load of $10 \mathrm{~kg}$ was performed on transverse root sections within $2 \mathrm{~mm}$ from the inner surface. Transverse weld tensile testing was conducted on double specimens taken at 6 and 12 o'clock. Root and side bend tests were carried out on specimens using a mandrel with a diameter of $4 \times \mathrm{t}$ and bent to $180^{\circ}$. The root bend specimens were taken from 4 and 10 o'clock and side bend samples at 2 and 7 o'clock. Subsize $(5 \times 10 \times 55 \mathrm{~mm})$ Charpy $\mathrm{V}$ impact tests specimens were prepared from the root weld area of the joint and tested at $-46^{\circ} \mathrm{C}$ and $-65^{\circ} \mathrm{C}$. The samples were taken from 1 and 5 o'clock. Scanning electron microscopy (SEM) was performed on the fracture surface of select impact specimens, with a Phillips FEG-SEM XL30. Pitting corrosion resistance testing was carried out using $6 \mathrm{M} \mathrm{FeCl}_{3}$ in accordance with ASTM G48 Method A [15]. The specimen size was $25 \times 50 \times 23.01 \mathrm{~mm}$ and they were obtained from the 3 o'clock position. All saw-cut sides 
were polished to a P600 finish. No passivation or pickling was applied after welding. Both the external and internal weld caps were left in the as-welded condition. The test duration was $24 \mathrm{~h}$ at a temperature of $23^{\circ} \mathrm{C}$. Nitrogen analysis was performed on the deposited root weld metal using the Leco combustion technique.

\section{RESULTS}

Radiographic inspection showed sound welds free from defects. The tensile tests all fractured in the base material at almost identical tensile strength $(765 \pm 6 \mathrm{MPa})$. All side bend tests were free from defects. The root bend tests were acceptable, apart from a $2.5 \mathrm{~mm}$ fissure found in one of the samples welded with $\mathrm{Ar}+20 \% \mathrm{~N}_{2}$. Subsequent micro and SEM analysis identified this defect as lack of fusion near the root surface. Hardness results are shown in Table 4 . Ar $+2 \% \mathrm{~N}_{2}$ provided the lowest hardness values when compared with all other specimens. The backing gas had no clear effect on the root weld metal hardness.

Table 4: Vickers microhardness measurements (HV 10)

\begin{tabular}{llllll}
\hline \multirow{2}{*}{ Location } & \multicolumn{2}{l}{ Backing gas composition } & & \\
& $\mathbf{1 0 0 \%} \mathbf{A r}$ & $\mathbf{A r}+\mathbf{2 \%} \mathbf{N}_{\mathbf{2}}$ & $\mathbf{A r}+\mathbf{1 0 \%} \mathbf{N}_{\mathbf{2}}$ & $\mathbf{A r}+\mathbf{2 0 \%} \mathbf{N}_{\mathbf{2}}$ & $\mathbf{1 0 0}_{\mathbf{0}} \mathbf{N}_{\mathbf{2}}$ \\
\hline Base material & $277 \pm 18$ & $263 \pm 3$ & $281 \pm 7$ & $278 \pm 17$ & $267 \pm 2$ \\
HAZ root & $307 \pm 7$ & $284 \pm 6$ & $296 \pm 8$ & $304 \pm 12$ & $304 \pm 12$ \\
FL root & $311 \pm 16$ & $292 \pm 6$ & $303 \pm 4$ & $309 \pm 1$ & $304 \pm 4$ \\
Weld root & $315 \pm 8$ & $297 \pm 5$ & $305 \pm 5$ & $314 \pm 12$ & $310 \pm 8$ \\
\hline
\end{tabular}

The microstructure of the root is shown in Figure 1. Most secondary austenite due to reheating was found for the sample welded with pure argon, where the surface also showed some nitrogen depletion and presence of chromium nitrides. There was no evidence of any detrimental phases such as sigma or chi phase in the root area nor the weld metal. The austenite content increased with nitrogen in the backing gas. Figure 2 shows the values measured for the root weld metal, HAZ and adjacent base metal. The highest volume fraction of ferrite recorded was when using pure argon as backing gas. These values decreased as nitrogen was added to the backing gas. The difference between the backing gases was small, but the lowest weld root ferrite content was measured for $\mathrm{Ar}+20 \% \mathrm{~N}_{2}$.
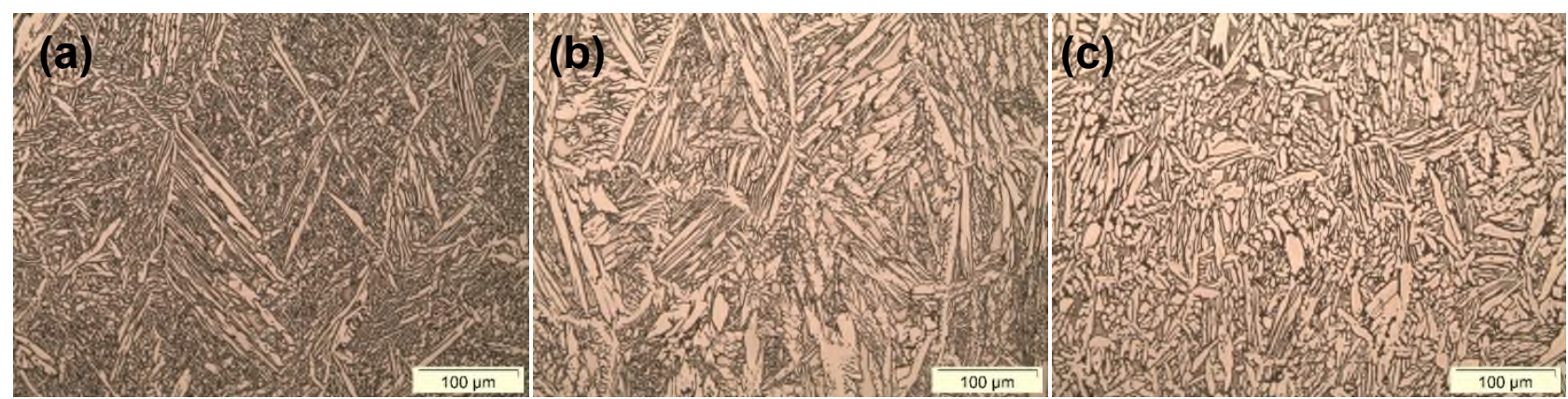

Figure 1: Root weld microstructure of (a) $100 \% \mathrm{Ar}$, (b) $\mathrm{Ar}+2 \% \mathrm{~N}_{2}$ and (c) $100 \% \mathrm{~N}_{2}$. The ferrite phase is here dark and austenite bright 


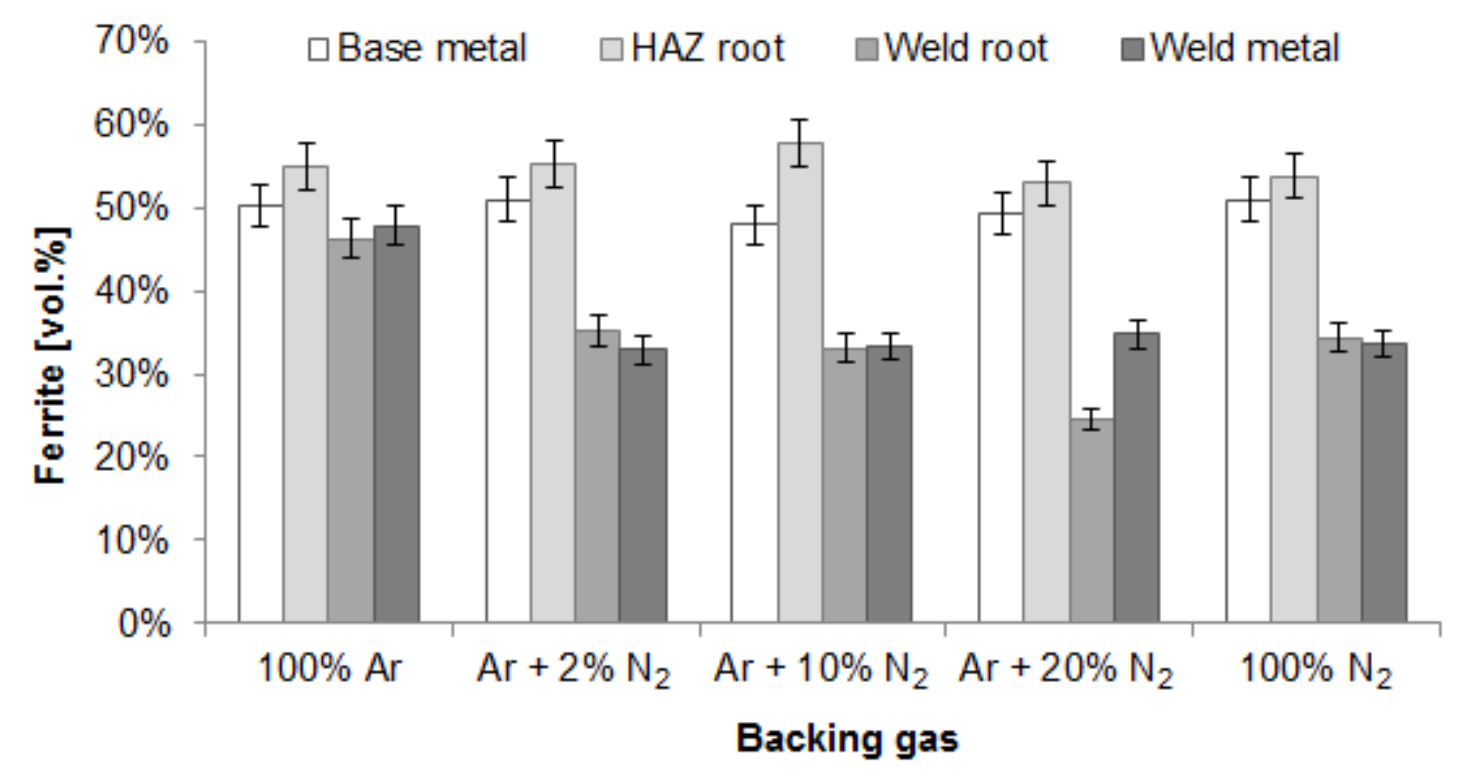

Figure 2: Ferrite content measured in the root pass, HAZ and base metal for different backing gas compositions

Figure 3 presents the impact toughness at $-46^{\circ} \mathrm{C}$ and $-65^{\circ} \mathrm{C}$. At $-46^{\circ} \mathrm{C}$ pure argon showed the highest value and $\mathrm{Ar}+10 \% \mathrm{~N}_{2}$ the lowest average value, but there was no apparent correlation with the backing gas composition. At $-65^{\circ} \mathrm{C}$ the average impact toughness increased and the standard deviation decreased with nitrogen content in the backing gas.

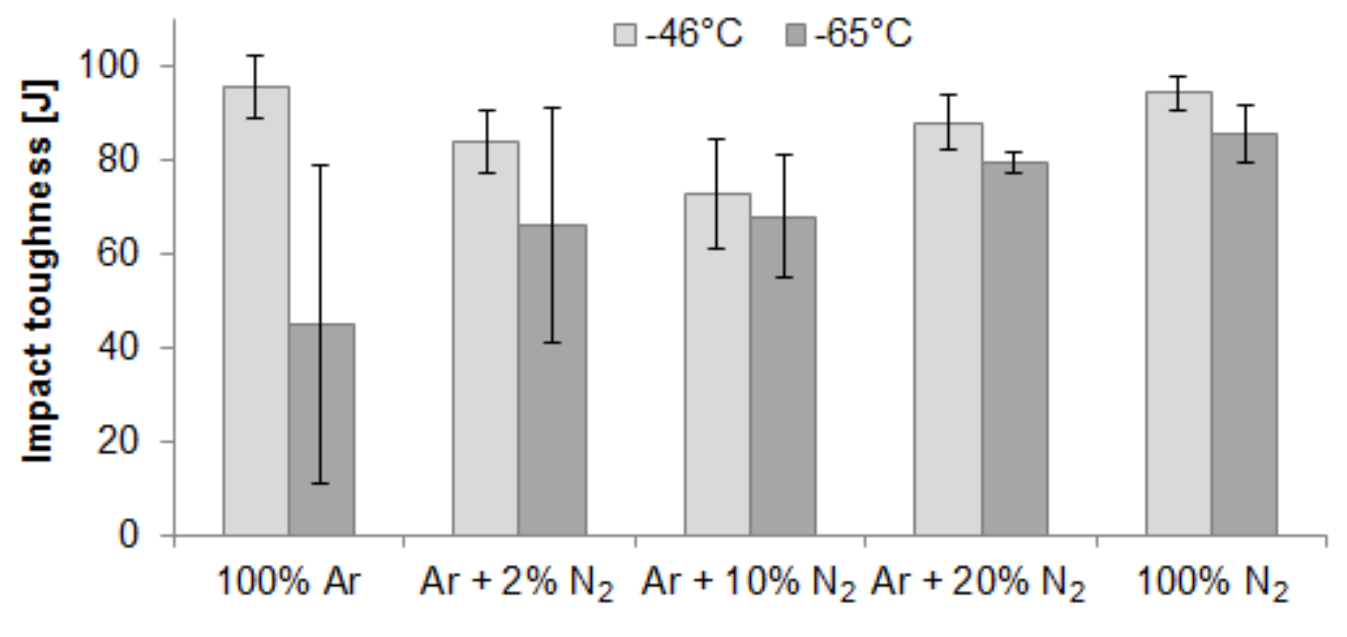

\section{Backing gas}

Figure 3: Energy absorption at $-46^{\circ} \mathrm{C}$ and $-65^{\circ} \mathrm{C}$ for different backing gas compositions

The SEM fracture surface assessment of the CVN impact samples is presented in Table 5. A limited number of samples were selected based on the highest and lowest values from impact testing.

Table 5: CVN specimens that underwent SEM analysis

\begin{tabular}{llllll}
\hline Sample & Backing gas & Location & Test temperature $\left[{ }^{\circ} \mathbf{C}\right]$ & Absorbed energy [J] & Failure \\
\hline 1a & $100 \% \mathrm{Ar}$ & Root weld & -46 & 103 & Ductile \\
$1 \mathrm{~b}$ & $100 \% \mathrm{Ar}$ & Root weld & -65 & 22 & Brittle \\
$5 \mathrm{a}$ & $100 \% \mathrm{~N}_{2}$ & Root weld & -46 & 97 & Ductile \\
$5 \mathrm{~b}$ & $100 \% \mathrm{~N}_{2}$ & Root weld & -65 & 80 & Ductile \\
\hline
\end{tabular}

Visual examination of the CVN fracture surfaces showed a ductile appearance with significant lateral expansion for all samples apart from the argon sample tested at $-65^{\circ} \mathrm{C}$. SEM examination of the argon sample tested at 
$-46^{\circ} \mathrm{C}$ showed that the notch root had torn on slightly different planes during testing with dimpled areas indicating ductile behaviour. The area just below the notch was mostly dimpled with some flat features, which also had some evidence of dimples. Higher magnification of the apparently ductile areas showed well-formed dimples (Figure 4a). The argon sample tested at $-65^{\circ} \mathrm{C}$ showed mixed appearance of dimples and flat features. There were ridges perpendicular to the notch associated with the flat regions and one separating flat areas from the dimpled areas. The amount of dimpled areas was significantly less than that tested at $-46^{\circ} \mathrm{C}$ and this also reflects the lower impact toughness of this sample. The flat facets were not completely devoid of deformation as some dimples were evident (Figure 4b). Both samples welded with pure nitrogen as backing gas showed some tearing parallel to the root of the notch and in higher magnification dimpled appearance (Figures 4c and 4d). The approximate mid thickness area also showed dimpled appearance.
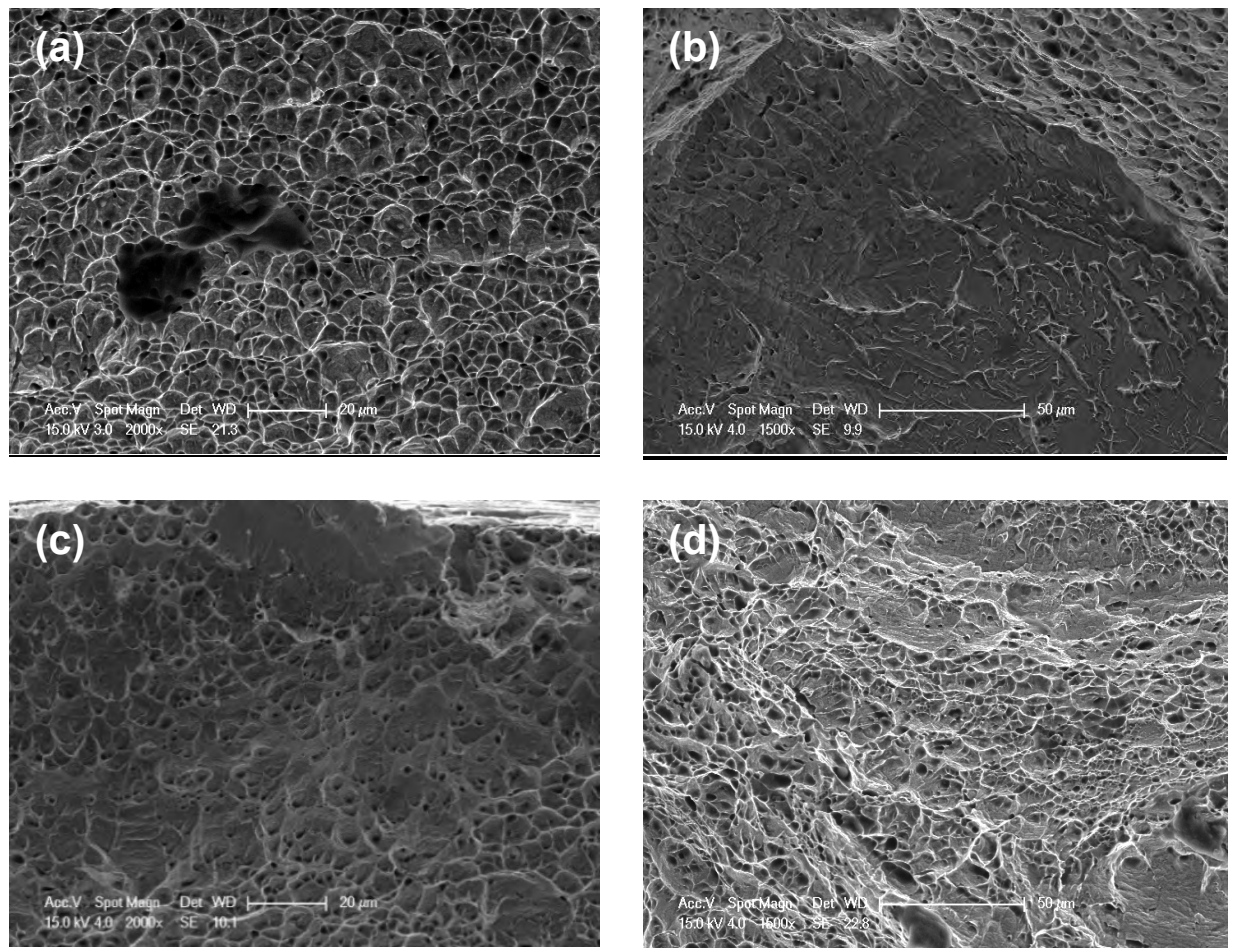

Figure 4: SEM fracture surface of root weld (a) pure argon at $-46^{\circ} \mathrm{C}$ showing evidence of a ductile fracture with dimples (b) pure argon at $-65^{\circ} \mathrm{C}$ with area of notably less plastic deformation, (c) pure nitrogen at $-46^{\circ} \mathrm{C}$ showing dimpled area typical of ductile fracture (d) pure nitrogen at $-65^{\circ} \mathrm{C}$ with dimpled area typical of ductile fracture

Table 6 summarises the pitting corrosion test results. The highest weight loss occurred when pure argon was used as a backing gas and pitting was also found in the weld root as shown in Figure 5 . Ar $+2 \% \mathrm{~N}_{2}$ showed small weight loss, but no pitting. All backing gas compositions with higher nitrogen content had no measurable weight loss.

Table 6: Pitting corrosion resistance as per ASTM G48A at $23^{\circ} \mathrm{C}$

\begin{tabular}{lllll}
\hline Test piece & Specimen size $[\mathbf{m m}]$ & Initial weight $[\mathbf{g}]$ & Final weight $[\mathrm{g}]$ & Weight loss $\left[\mathrm{g} / \mathbf{m}^{2}\right]$ \\
\hline $100 \% \mathrm{Ar}$ & $50.0 \times 25 \times 23.21$ & 236.07 & 235.92 & 25.21 \\
$\mathrm{Ar}+2 \% \mathrm{~N}_{2}$ & $50.0 \times 25 \times 22.55$ & 225.68 & 225.67 & 1.70 \\
$\mathrm{Ar}+10 \% \mathrm{~N}_{2}$ & $50.0 \times 25 \times 22.75$ & 231.33 & 231.33 & 0.00 \\
$\mathrm{Ar}+20 \% \mathrm{~N}_{2}$ & $50.0 \times 25 \times 23.10$ & 233.44 & 233.44 & 0.00 \\
$100 \% \mathrm{~N}_{2}$ & $50.1 \times 25 \times 23.55$ & 238.70 & 238.70 & 0.00 \\
\hline
\end{tabular}



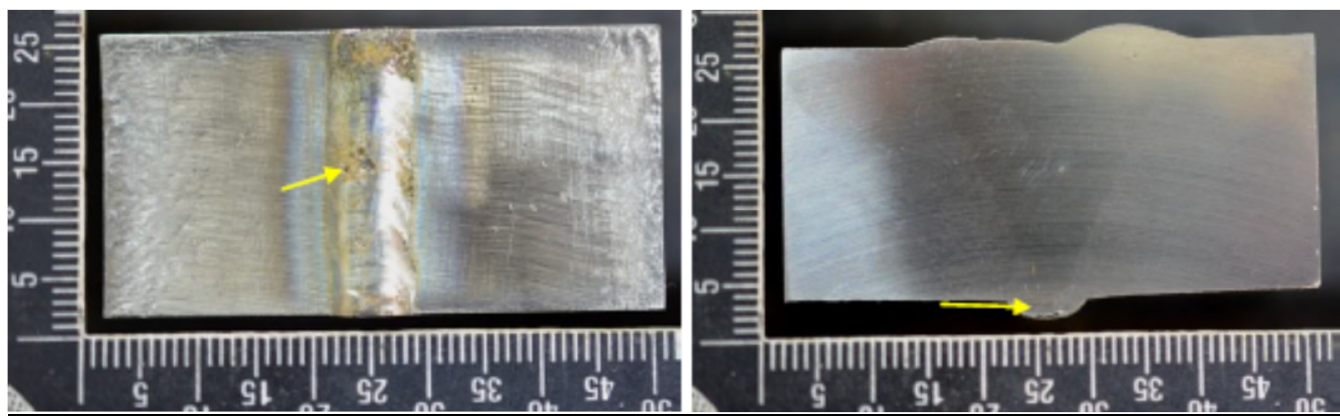

Figure 5: Sample welded with pure argon showing evidence of pitting after corrosion testing (arrows).

Table 7 shows the Leco analysis of nitrogen in the root weld area. The argon weld was depleted in nitrogen. The nitrogen content increased with $\mathrm{Ar}+2 \% \mathrm{~N}_{2}$ backing gas and reached the solubility limit with $\mathrm{Ar}+10 \% \mathrm{~N}_{2}$ and did not increase further when adding more than $10 \% \mathrm{~N}_{2}$ to the backing gas.

Table 7: Weld metal nitrogen content in the root pass. Measured by Leco (wt.\%)

\begin{tabular}{ll}
\hline Backing gas & Nitrogen \\
\hline $100 \% \mathrm{Ar}$ & 0.11 \\
$\mathrm{Ar}+2 \% \mathrm{~N}_{2}$ & 0.17 \\
$\mathrm{Ar}+10 \% \mathrm{~N}_{2}$ & 0.21 \\
$\mathrm{Ar}+20 \% \mathrm{~N}_{2}$ & 0.20 \\
$100 \% \mathrm{~N}_{2}$ & 0.21 \\
\hline
\end{tabular}

\section{DISCUSSION}

The backing gas did not affect the transverse weld metal tensile test results as the samples failed in the base material. This is attributed to the overmatching strength of the filler metal. In addition, nitrogen did not have any significant influence on the hardness profile as all welds had a similar hardness.

From the phase balance measurements, the highest volume fraction of ferrite (46\%) was observed with $100 \% \mathrm{Ar}$ as the shielding and backing gas. The microstructure showed distinct ferrite grains with Widmanstätten and secondary austenite. The ferrite content decreased when adding nitrogen to the shielding and backing gas and resulted in an average level of 33-35\% in the weld metal and $25-35 \%$ in the root pass. The effect that nitrogen had on the root weld microstructure was a more refined microstructure with higher levels of austenite.

$100 \% \mathrm{Ar}$ as backing gas showed localized corrosion attack in the weld metal and corresponding high weight loss. This is correlated to nitrogen loss at the very surface resulting in higher weld metal ferrite content and exposing chromium nitrides to the corrosive medium $[8,12]$. Pitting takes preference to the ferrite phase. By adding nitrogen to the backing gas, localized corrosion was avoided. This is consistent with previous research $[8,12]$ concluding that the presence of nitrogen prevents nitrogen loss and forms a protective thin layer of austenite at the weld root surface, which assists to prevent pitting corrosion. With $\mathrm{Ar}+2 \% \mathrm{~N}_{2}$ there was still a small weight loss of $1.7 \mathrm{~g} / \mathrm{m}^{2}$ exceeding what is allowed in ASTM A923 $\left(1 \mathrm{~g} / \mathrm{m}^{2}\right)$. At least $10 \% \mathrm{~N}_{2}$ was required to pass the corrosion test and this is consistent with what has been reported elsewhere $[1,9,12]$. Leco analysis found that a nitrogen content of $>0.20 \%$ was obtained in the root weld metal with $\mathrm{Ar}+10 \% \mathrm{~N}_{2}, \mathrm{Ar}+20 \% \mathrm{~N}_{2}$ and $100 \% \mathrm{~N}_{2}$. With $\mathrm{Ar}+10 \% \mathrm{~N}_{2}$ the root weld metal nitrogen content had reached solubility level and no weight loss was measured for this gas type or higher nitrogen fractions. This is consistent with other research stating that at least $5 \%$ nitrogen in the backing gas is needed $[1,12]$.

CVN testing at $-46^{\circ} \mathrm{C}$ showed almost identical average impact toughness for pure argon and pure nitrogen (95 and $94 \mathrm{~J}$, respectively) and $\mathrm{Ar}+10 \% \mathrm{~N}_{2}$ the lowest average value (73 J). All samples showed a ductile failure mode and there was no apparent correlation with the backing gas composition. Increased nitrogen level in the backing gas did, however, have a positive effect at $-65^{\circ} \mathrm{C}$. The average impact toughness increased and the standard deviation decreased with nitrogen content in the backing gas. Pure argon had mean CVN of $45 \mathrm{~J}$, while pure nitrogen was as high as $85 \mathrm{~J}$, only $9 \mathrm{~J}$ lower than the result at $-46^{\circ} \mathrm{C}$. Nitrogen thus has a positive influence on impact toughness at lower temperatures. It is believed that the more uniform austenite formation plays a role as ferrite becomes more brittle at lower temperatures. Visual examination of the CVN fracture surfaces also showed less plastic deformation for pure argon impact samples tested at $-65^{\circ} \mathrm{C}$, while the pure nitrogen samples still showed ductile fracture. The samples made with $\mathrm{Ar}+2 \% \mathrm{~N}_{2}, \mathrm{Ar}+10 \% \mathrm{~N}_{2}$ and $\mathrm{Ar}+20 \% \mathrm{~N}_{2}$ as backing gas also showed ductile failure as compared to pure argon. 
Most duplex specifications and standards used in the oil and gas industry state that the average weld metal ferrite content should be $35-65 \%$ for optimum properties. The welds performed with pure argon had $48 \%$ ferrite, but did not pass the ASTM G48 pitting corrosion test. With nitrogen additions to the shielding and backing gas, the average weld metal ferrite content was in the lower range, 33-35\%, but then these welds passed the corrosion test and still showed good mechanical properties. This confirms that assessment of microstructure should be of informative character and not a cause of rejection. It is relevant to qualify a welding procedure by demonstrating with mechanical and corrosion testing that the procedure, when applied to the base material at the proposed thickness, will not deteriorate the toughness or corrosion resistance.

\section{CONCLUSIONS}

The effect of various levels of argon and nitrogen as backing gas on mechanical properties and corrosion resistance has been investigated for $23 \mathrm{~mm}$ thick 22Cr duplex pipes manually welded with ER2209 filler metal using the GTAW process. 100\% Ar as shielding and backing gas showed localized pitting corrosion and did not pass ASTM G48 testing. Use of nitrogen additions to the backing gas improved the resistance to pitting attack and at least $10 \%$ nitrogen was needed if the requirements of both ASTM G48 and ASTM A923 were to be met. The influence of nitrogen had no effect on transverse tensile and hardness values of the root weld. At $-46^{\circ} \mathrm{C}$ the impact toughness could not be correlated to the backing gas composition, but at $-65^{\circ} \mathrm{C}$ nitrogen had significant positive effect with lower standard deviation.

\section{REFERENCES}

[1] Pettersson C-O, Fager S (1995) Welding practice for the Sandvik duplex stainless steels SAF 2304, SAF 2205 and SAF 2507. Report Sandvik Steel S-91-57-ENG, Icoprint ab, Sandviken, Sweden; p 15

[2] Davison R, Redmond J (1991) A guide to using duplex stainless steels. Materials Design 12(4): 187-92

[3] Gunn, R (1997) Duplex stainless steels: Microstructure, properties and applications. Elsevier; p 216

[4] Karlsson L (2012) Welding of duplex stainless steels - A review of current recommendations. Weld World 56(5/6): 65-76

[5] Sieurin H, Sandström R (2007) Sigma phase precipitation in duplex stainless steel 2205. Materials Sci Eng A. $444(1): 271-276$

[6] Westin EM (2014) Optimisation of welding procedures for duplex and superduplex stainless steels. Australian Weld J. 59(1): 38-52.

[7] Westin EM, Johansson MM, Bylund L-Å, Pettersson RFA (2014) Effect on microstructure and properties of super duplex stainless steel welds when using backing gas containing nitrogen and hydrogen. Weld World. 58(3): 347-54

[8] Westin EM, Johansson MM, Pettersson RFA (2013) Effect of nitrogen-containing shielding and backing gas on the pitting corrosion resistance of welded lean duplex stainless steel LDX $2101 \AA(E N 1.4162$, UNS S32101). Weld World. 57(4): 467-76

[9] Matsunaga H, Sato Y, Kokawa H, Kuwana T (1998) Effect of nitrogen on corrosion of duplex stainless steel weld metal. Sci Tech Weld Joi 3(5): 225-32

[10] Svensson L, Gretoft B (1986) Properties-microstructure relationship for duplex stainless steel weld metals. Proc. Duplex Stainless Steel, The Netherlands, 288-294

[11] Nilsson J, Karlsson L, Andersson J (1995) Secondary austenite formation and its relation to pitting corrosion in duplex stainless steel weld metal. Materials Science and Technology 11(3):276-83

[12] Westin EM, Serrander D (2012) Experience in welding stainless steels for water heater applications. Weld World. 56: 5614-5628

[13] Kotecki DJ (2009) Some pitfalls in welding duplex stainless steels. Stainless Steel World. 21(12): 51-57

[14] Taban E (2008) Toughness and microstructural analysis of superduplex stainless steel joined by plasma arc welding. J Materials Sci. 43(12): 4309-4015

[15] Busschaert F, Cassagne T, Pedersen A, Johnsen S (2013) New challenges for the use of duplex stainless steels at low temperatures. Revue De Métallurgie. 110:185-97 
2016-04-22

\section{Effect of nitrogen in backing gas on duplex root weld properties of heavy-walled pipe}

Sales, A. M.

Springer

A. M. Sales, E. M. Westin and P. Colegrove. Effect of nitrogen in backing gas on duplex root weld properties of heavy-walled pipe. Welding in the World, September 2016, Volume 60, Issue pÿ5, pp877 882

http://dx.doi.org/10.1007/s40194-016-0347-3

Downloaded from Cranfield Library Services E-Repository 